\title{
Meiobenthos in earthen ponds used for semi-intensive shrimp farming (New Caledonia, South Pacific)
}

\author{
Della Patrona Luc ${ }^{2}$, Bianchelli Silvia ${ }^{1}$, Beliaeff Benoit ${ }^{2}$, Pusceddu Antonio 1, *
}

1 Polytech Univ Marche, Dept Life \& Environm Sci, Ancona, Italy.

2 IFREMER, Dept Lagons Ecosyst \& Aquaculture Durable LEAD NC, Noumea, New Caledonia.

* Corresponding author : Antonia Pusceddu, email address : a.pusceddu@univpm.it

\begin{abstract}
:
We analysed the temporal variability of meiobenthic (meiofauna and protists) abundance and community structure in the sediments of two shrimp farms located in New Caledonia. In each farm, sediment samples were collected weekly from February to June 2006 at two ponds, and analysed for quantity and composition of sedimentary organic matter, meiofaunal abundance, taxa richness and community composition. Independently of the initial conditions, sedimentary contents of biopolymeric $\mathrm{C}$ and total phytopigment varied significantly during shrimp rearing, although not consistently in the two ponds. Changes in the quantity and biochemical composition of sedimentary organic matter were associated with changes in total meiofaunal abundance and taxa richness, as well as in total and rare $(<1 \%$ of total abundance) meiobenthic community composition. We show that the slight eutrophication of the sediment during the shrimp rearing cycle determined significant effects on the meiofaunal community composition as well as on the relative importance of metazoan vs. protists abundance. The results of this study suggest that the study of meiobenthic communities represents a reliable descriptor of the environmental quality of shrimp farming ponds.
\end{abstract}

Keywords : shrimp farming, meiobenthos, New Caledonia, Pacific Ocean 


\section{Introduction}

Aquaculture is increasingly becoming one of the most important industries having effects on coastal and offshore oceans worldwide [1]. Aquaculture activities are, in fact, relevant on local and regional scales all over the world, placed in different environments (coastal, off-shore, natural and artificial enclosed or semi-enclosed basins) and conducted using different densities of numerous reared species and different feeding practices (i.e. semi-intensively or intensively [2]).

Among the many aquaculture practices, intensive shrimp farming in earthen ponds is growing almost exponentially in several areas of the South Pacific. There are severe concerns about the environmental sustainability of this activity, the effects of which can spread well beyond the earthen ponds [3-5]. In fact, despite the considerable development, and even though shrimp farming is perceived to be more environmentally safe than other practices of reared resource exploitation [6], there is evidence that this activity may have adverse environmental impacts [7-14]. 
Typically, semi-intensive and intensive aquaculture installations in natural basins can produce shifts in the whole environment, also affecting the quality of neighbouring sites [15-17]. The impacts of shrimp farms on earthen ponds and neighbouring ecosystems are generally monitored using water column variables (i.e. phytoplankton biomass or nutrient concentrations and mass balances) [18-20]. However, very few investigations have been carried out to evaluate the impact of shrimp farming activities on the trophic status [2] and meiofaunal assemblages [21] of shrimp pond sediments.

Among the different benthic organisms, meiofauna are highly sensitive to environmental disturbance associated with organic enrichment and benthic eutrophication [22-25]. In this regard, several studies have addressed the response of meiofauna to hypoxic conditions or benthic organic enrichment [26-28]. Indeed, due to their relatively short life cycles, high turnover rates and lack of larval dispersion, meiofauna respond rapidly to many different environmental changes [29-35]. In this regard, several studies have highlighted that biodeposition from offshore fish farming activities provokes changes in meiofaunal abundance, community structure and biodiversity, although these studies have not revealed consistent responses among different regions and/or habitats [24,27,32].

In this study, we analysed the temporal variability in meiobenthos abundance and community structure in the sediments of two shrimp farms located on the southern coast of New Caledonia, characterised by peculiar differences in shrimp feeding practices and levels of initial trophic conditions. The aim of this study was to assess the meiofaunal response to changes in the whole trophic status of the earthen pond sediments under scrutiny.

\section{Materials and methods}

\subsection{Study area and sediment sampling}

The study was conducted in two semi-intensive shrimp farms: Sea Farm (F) and Saint Vincent (V), located on the west coast of New Caledonia's Main Island, also known as Grande Terre (Figure 1). The shrimp growing cycle lasts $\sim 4$ months, at the end of which the shrimps are harvested and the ponds are left to dry for several weeks. Once dried, the sediments are ploughed to oxidise the remains of organic matter and other reduced substances. Water renewal in the farming ponds is ensured by a water-exchange system supplying open seawater with a salinity of between 32 and 39 . Artificial feeding is provided at rates ranging from $\sim 6$ to $60 \mathrm{~kg} \mathrm{ha}^{-1} \mathrm{~d}^{-1}$. More details about the shrimp rearing cycles and feeding practices during this study are reported elsewhere [2]. Briefly, from 1992 to 2003 farm $F$ consisted of 10 ponds, built on salt marshes adjacent to a mangrove forest, each $\sim 3$ ha. All ponds used high shrimp density (up to 30-45 individuals $\cdot \mathrm{m}^{-2}$ ), and were subjected to moderate forced aeration (using paddlewheel-like aerators with $3-5$ horse power $\cdot \mathrm{ha}^{-1}$ power) and a maximum water exchange of up to $30 \%$ per day at the end of the rearing cycle. After repeated poor yields of the farming activity, the number of ponds was reduced to four, by cutting the dykes, thus increasing the surface of the remaining ponds to 7-8.5 ha. The bottom of the ponds was not treated in any way and local sediment accumulation due to rotating currents was left in place. Shrimp density was also sensibly reduced to $18-20$ individuals $\cdot \mathrm{m}^{-2}$ and forced aeration was no longer used. Since 2003, management of farm F shrimp ponds in terms of water exchange, feeding practices and stocking density has been the same as used for farm V (see below for further details). For this investigation, we focused our attention on a 6.9-ha surface pond in farm $\mathrm{F}$, characterised by a depth ranging from $\sim 0.5 \mathrm{~m}$ (inlet) to $\sim 1.3 \mathrm{~m}$ (outlet), a shrimp stocking density maintained at $\sim 20$ individuals $\cdot \mathrm{m}^{-2}$ and a feeding practice of 18 cycles at a total amount of released pellet food of $13.9 \mathrm{~kg} \cdot \mathrm{m}^{-2}$ [2].

' $\mathrm{V}$ ' is an experimental farm consisting of 21 ponds with a surface varying from 0.05 to 3 ha, built on fertile salt pans adjacent to a mangrove forest. In these ponds, low-to-moderate shrimp densities 

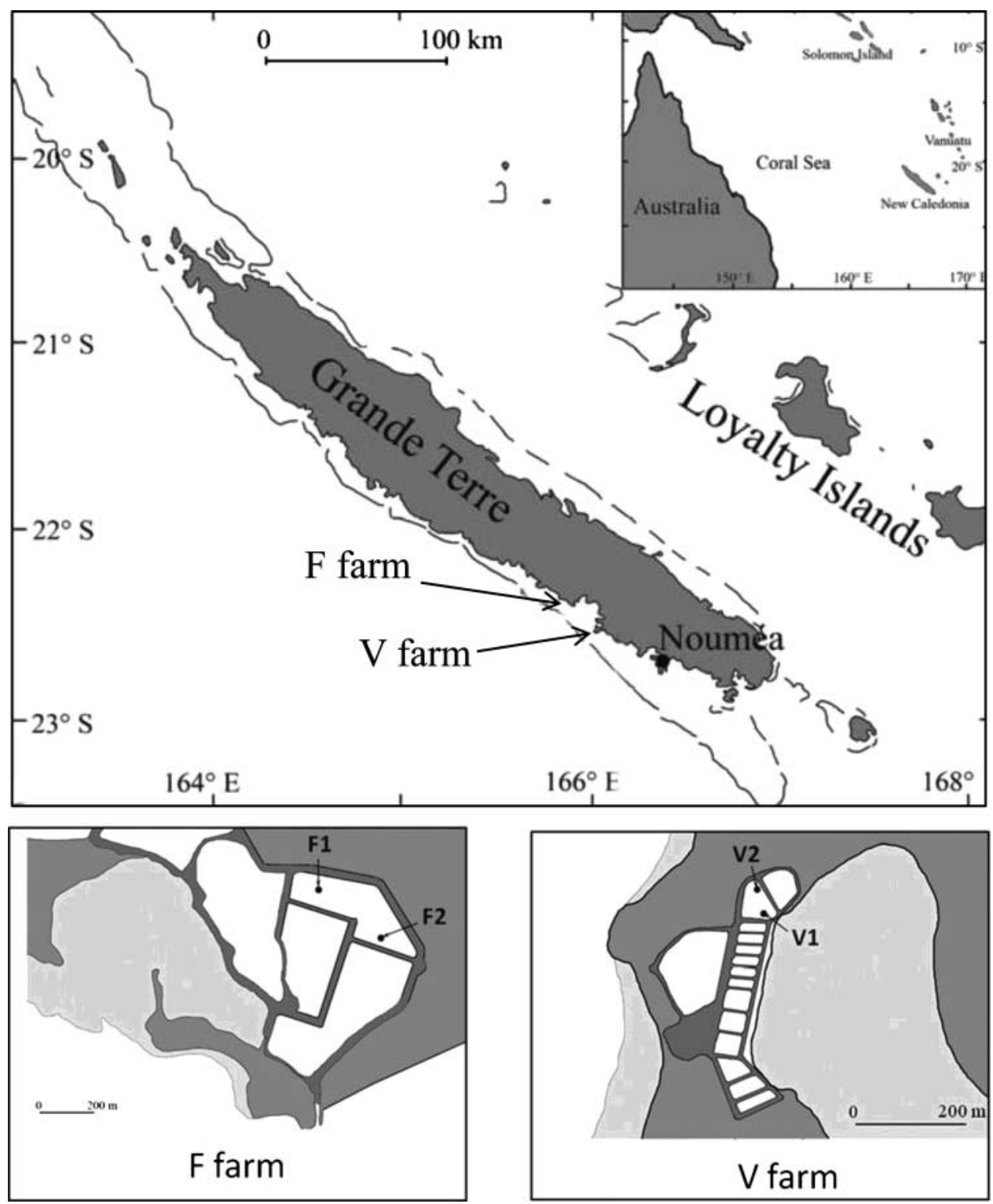

Figure 1. Study area and location of shrimp farms and ponds.

(16-20 individuals $\cdot \mathrm{m}^{-2}$ ) are typically reared using optimised feeding practices (12 cycles for a total of $5.4 \mathrm{~kg} \cdot \mathrm{m}^{-2}$ pellet given) and without aeration.

In each shrimp farm, sediment samples were collected from two ponds (F1 and F2 in Sea Farm and V1 and V2 in Saint Vincent) on a weekly basis from February to June 2006. At each pond, sediment sampling started immediately after filling the ponds with seawater and stopped just before shrimp harvesting. Sediment samples were collected in triplicate for meiofaunal analysis by means of Plexiglas cores (inner diameter $3.6 \mathrm{~cm}$, corresponding to $\sim 10.7 \mathrm{~cm}^{2}$ surface area) to a depth of $2 \mathrm{~cm}$. Sediment samples were immediately fixed with buffered $4 \%$ formaldehyde solution until laboratory analyses and stained with a few drops of Rose Bengal $\left(0.5 \mathrm{~g} \cdot \mathrm{L}^{-1}\right)$. 
Additional triplicate sediment samples (top $2 \mathrm{~cm}$ ) for biochemical analyses of sedimentary organic matter were collected using Plexiglas tubes (inner diameter $4.7 \mathrm{~cm}$ ) manually and gently inserted into the sediment and immediately frozen at $-20^{\circ} \mathrm{C}$ until analyses in the laboratory (within 1 week).

At each pond and sampling date, portions of the bottom were isolated using polyvinyl chorlide (PVC) corers $\left(\sim 490 \mathrm{~cm}^{3}\right)$ manually inserted into the sediment. Redox potential and $\mathrm{pH}$ measurements were taken from the top few centimetres of the sediment using specific electrodes connected to $\mathrm{pH}$ and $\mathrm{mV}$ meters (ISFET Scientific Instruments, WTW315i, respectively). Data on sediment oxygen demand, temperature, salinity, dissolved oxygen, turbidity, total alkalinity and ammonium concentrations are reported elsewhere [2].

\subsection{Meiofaunal analyses}

Sediment samples were sieved through a $1000-\mu \mathrm{m}$ mesh, and a $32-\mu \mathrm{m}$ mesh was used to retain the smallest organisms. The fraction remaining on the latter sieve was resuspended and centrifuged three times with Ludox HS40 (diluted with water to a final density of $1.18 \mathrm{~g} \cdot \mathrm{cm}^{-3}$ ) [36,37]. Meiobenthos from three independent replicates per pond and sampling date were counted and sorted by higher taxa under a stereomicroscope after staining with Rose Bengal $\left(0.5 \mathrm{~g} \cdot \mathrm{L}^{-1}\right)$. The rare meiofaunal taxa were defined as the taxa representing $<1 \%$ of the total meiofaunal abundance [38].

\subsection{Sedimentary organic matter}

Chlorophyll $a$ and phaeopigment analyses were determined fluorometrically and their sum defined as total phytopigments [39]. The protein, carbohydrate and lipid contents of the sediments were determined spectrophotometrically [2,39]. The protein, carbohydrate and lipid sediment contents were converted into carbon equivalents using the conversion factors $0.49,0.40$ and $0.75 \mathrm{mgC} \cdot \mathrm{mg}^{-1}$, respectively, and their sum was defined as the biopolymeric organic carbon [2,39]. All of the analyses were performed as three replicates, with $\sim 1 \mathrm{~g}$ of surface sediment $(0-1 \mathrm{~cm}$ sediment depth) for each sample. Details on the variations in the biochemical composition of sedimentary organic matter in the investigated ponds are reported elsewhere [2]. In this study, we report only variations in the concentrations of biopolymeric $\mathrm{C}$ and total phytopigment concentrations assumed as reliable synthetic descriptors of the benthic trophic status [25,39].

\subsection{Statistical analyses}

Spatial-temporal variations in all investigated variables (total abundance, single taxon abundance and richness of taxa) were investigated by means of a two-way analysis of variance (ANOVA), with pond (F1, F2, V1 and V2 ponds) and sampling time as major sources of variance. The design included two factors: (1) pond (four fixed levels) and (2) time (17 fixed levels orthogonal to pond). Before the ANOVAs, the homogeneity of the variances was checked using Cochran's test, and the data not-normally distributed were appropriately transformed to meet such assumption, wherever necessary. When significant differences between fixed levels were observed, a post-hoc Student-Newman-Kuels (SNK) test $(\alpha=0.05)$ was also carried out.

Multivariate permutational analyses of variance (PERMANOVA) were also carried out to analyse spatial-temporal variability in the composition of: (1) the whole and (2) the rare meiobenthic taxa communities. These analyses, based on Bray-Curtis similarity matrices of untransformed data (for the meiofaunal taxonomic composition) or after the presence/absence transformation of the data (for the rare taxa composition), were carried out using 4999 random permutations of 
Table 1. Results of univariate ANOVA testing for spatial-temporal variability in total meiobenthos abundance and richness of taxa.

\begin{tabular}{lrrrr}
\hline Source & DF & MS & $F$ & $p$ \\
\hline Total abundance & & & & \\
Station & 2 & $74,892,948.6$ & 6.0 & - \\
Time & 16 & $24,104,830.8$ & 9.8 & - \\
Station $\times$ Time & 48 & $12,450,821.0$ & 5.1 & $* * *$ \\
Residual & 136 & $2,449,643.5$ & & \\
Total & 203 & & & \\
Taxa richness & & & & \\
Station & 3 & 18.4 & 11.9 & - \\
Time & 16 & 2.2 & 4.3 & - \\
Station $\times$ Time & 48 & 1.5 & 3.0 & $* * *$ \\
Residual & 136 & 0.5 & & \\
Total & 203 & & & \\
\hline
\end{tabular}

Notes: DF, degrees of freedom; MS, mean square; $F, F$ ratio; $* * * p>0.001$.

the appropriate units under reduced models [40]. A two-way SIMPER analysis was also applied to identify which taxa contributed most to the observed spatial-temporal dissimilarities among ponds, sampling times within each pond and ponds within each sampling time. The observed differences were finally visualised using bi-plots derived after a canonical analysis on principal coordinates (CAP), aimed at assigning ponds and sampling times to categories identified a priori. For PERMANOVA, SIMPER and CAP analyses, the design included two factors: (1) pond (four fixed levels) and (2) time (17 fixed levels orthogonal to pond). PERMANOVA, SIMPER and CAP analyses were carried out using the Primer6+ package [41]. Although time should be considered as a random factor, we forced its use as a fixed factor and imposed the use of post-hoc tests to identify significant peaks and eventual temporal trends in all investigated variables and their multivariate combinations.

To assess whether and how much physicochemical and trophic (i.e. biopolymeric $\mathrm{C}$ and total phytopigment sedimentary contents) variables explained changes in total abundance, taxa richness and taxonomic composition (for both the whole and rare taxa communities) non-parametric multivariate multiple regression analyses, based on Bray-Curtis dissimilarity matrixes, were carried out using the routine DISTLM forward [42]. The forward selection of the predictor variables was carried out with tests by permutation. In addition to sediment $\mathrm{pH}$ and redox potential, total phytopigment and biopolymeric sedimentary concentrations, explanatory variables also included: food provided to the shrimps, sedimentary contents of chlorophyll $a$, phaeopigment, protein, carbohydrate, lipid, total organic matter and oxygen concentrations. Details of all these variables are reported elsewhere [2].

\section{Results}

\subsection{Physicochemical characteristics and sedimentary organic matter of the ponds}

At all $\mathrm{F}$ and $\mathrm{V}$ sites sediment $\mathrm{pH}$ and redox were characterised by significant temporal variability (Figure 2). At all sites, $\mathrm{pH}$ values in the sediment generally decreased from March to May, to increase again in June. Values of the sedimentary redox potential (Eh) decreased sharply in all sites from February to March, to increase again through June. Eh values in F2 were generally lower than at all other sites. Sedimentary contents of biopolymeric $\mathrm{C}$ and total phytopigment concentrations showed significant temporal variations but with variable patterns in the four ponds (Figure 3 ). In F1, total phytopigment sedimentary contents decreased over the study period, whereas in F2 values 

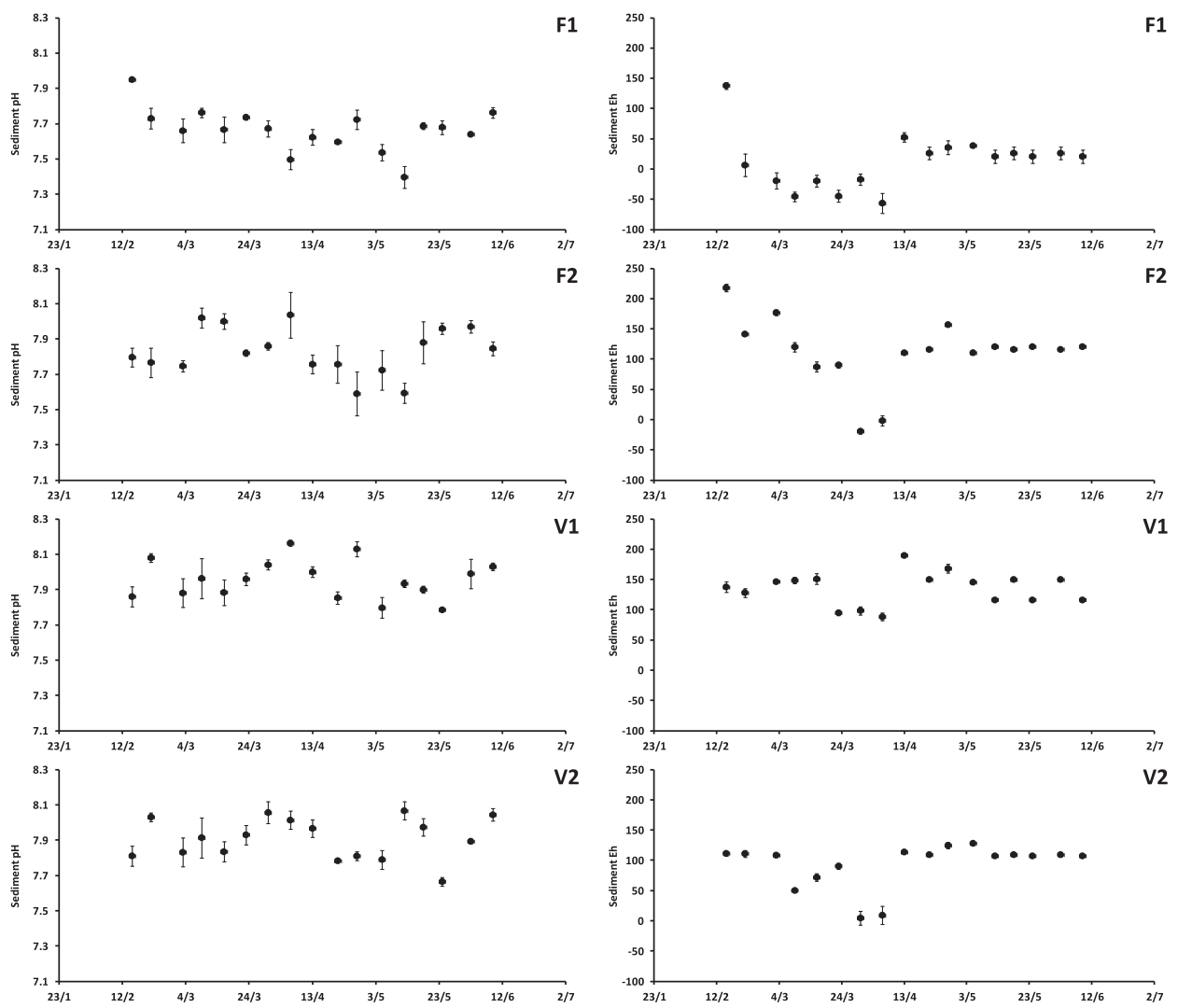

Figure 2. Temporal variations in sediment $\mathrm{pH}$ and redox potential (Eh) values in the four investigated ponds.

increased. In V1, total phytopigment sedimentary contents did not display significant temporal variations, whereas in V2 values decreased until March and then remained nearly constant to the end of the study. In F1 and F2, sedimentary biopolymeric C contents increased progressively during the entire study period. In $\mathrm{V} 1$ sediments, concentrations of biopolymeric $\mathrm{C}$ were generally lower than those in all other ponds and did not display significant temporal variations. In V2, sedimentary biopolymeric $\mathrm{C}$ contents decreased progressively over the entire study period.

\subsection{Variability of meiobenthic abundance, taxa richness and community composition}

Temporal variations in total abundance and richness of meiobenthic taxa at all the investigated ponds are illustrated in Figures 4 and 5. Univariate ANOVA revealed that both abundance and richness of meiobenthic taxa were characterised by a significant effect of the Pond $\times$ Time interaction (Table 1). The SNK tests (data not shown) revealed significant differences in the meiobenthic abundance and richness of taxa among ponds at almost all sampling times, but with variable and inconsistent patterns. SNK tests also revealed that at all ponds the abundance of meiofauna and protists peaked significantly in February and May, and reached the lowest values in March (Table 1). In the F1 and F2 ponds, the richness of taxa decreased with time, whereas in V1 and V2 peaked in February and May.

In this study, eight meiofaunal taxa (nematodes, copepods, polychaetes, oligochaetes, kinorhynchs, ostracods, insecta and rotifers), and two major taxa of protists (ciliates and forams) were identified. Kinorhynchs were found exclusively in F1. 

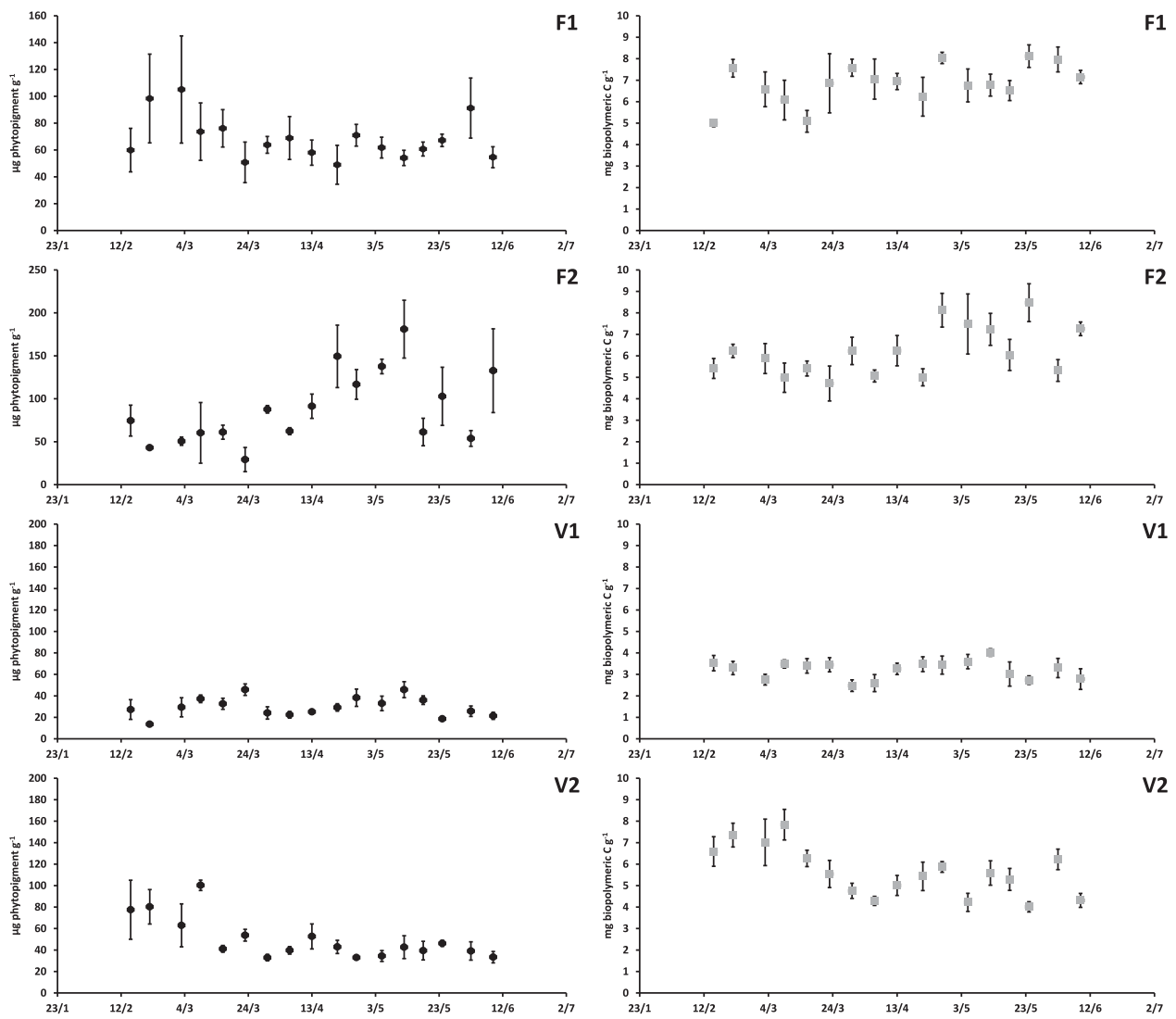

Figure 3. Temporal variations in total phytopigment and biopolymeric $\mathrm{C}$ sedimentary contents in the four investigated ponds.

Table 2. Results of permutational ANOVA testing for spatial-temporal changes in the meiobenthic community composition.

\begin{tabular}{lrrrr}
\hline Source & DF & \multicolumn{1}{c}{ MS } & \multicolumn{1}{c}{$F$} & $p$ \\
\hline Pond & 3 & 24,375 & 41.8 & - \\
Time & 16 & 8646 & 14.8 & - \\
Pond $\times$ Time & 48 & 3168 & 5.4 & $* * *$ \\
Residual & 136 & 583 & & \\
Total & 203 & & & \\
\hline
\end{tabular}

Notes: DF, degrees of freedom; MS, mean squares; ***p $<001$.

Temporal variation in the meiobenthic community structure at the ponds under scrutiny is illustrated in Figure 6. At all ponds, depending on the sampling time, the dominant taxa were nematodes, copepods and rotifers (ranging cumulatively from 8 to 96\%) or protists (forams and ciliates, ranging cumulatively from 4 to $92 \%$ ).

The PERMANOVA, conducted to assess changes in the composition of meiobenthic communities, revealed a significant effect of the Pond $\times$ Time interaction (Table 2). The composition of the meiobenthic communities changed among sampling periods at each pond, but with variable patterns (Figure 6). The SIMPER analyses revealed that changes in relative abundance of nematodes, copepods, rotifers, ciliates and foraminifera were responsible for the observed spatial and temporal dissimilarities (up to $99.9 \%$; Table 3). The SIMPER analysis also revealed that at each 

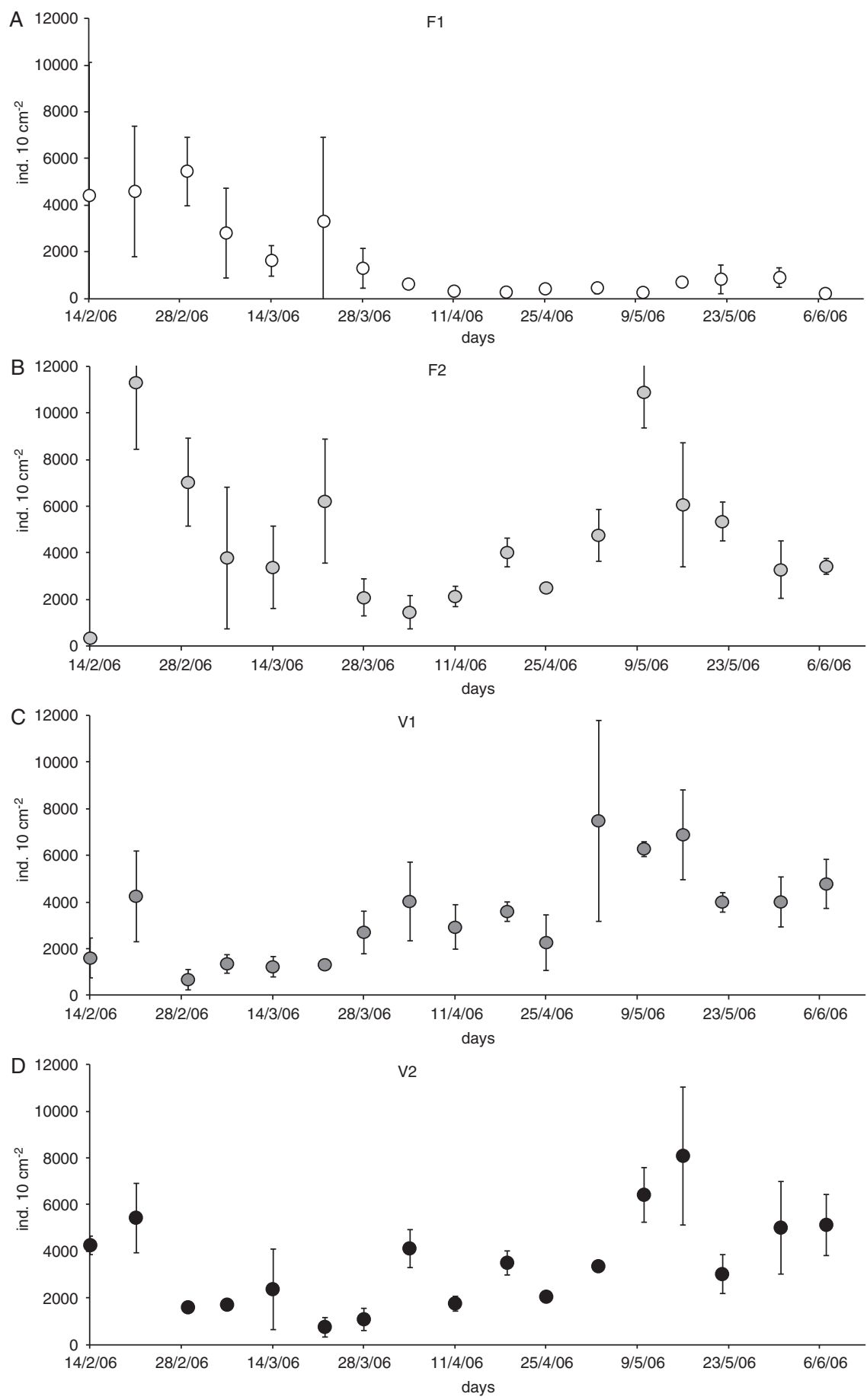

Figure 4. Meiobenthic abundance at all investigated ponds in all sampling times: (A) F1 (Sea Farm), (B) F2 (Sea Farm), (C) V1 (Saint Vincent) and (D) V2 (Saint Vincent). Values are displayed as means \pm SD. 

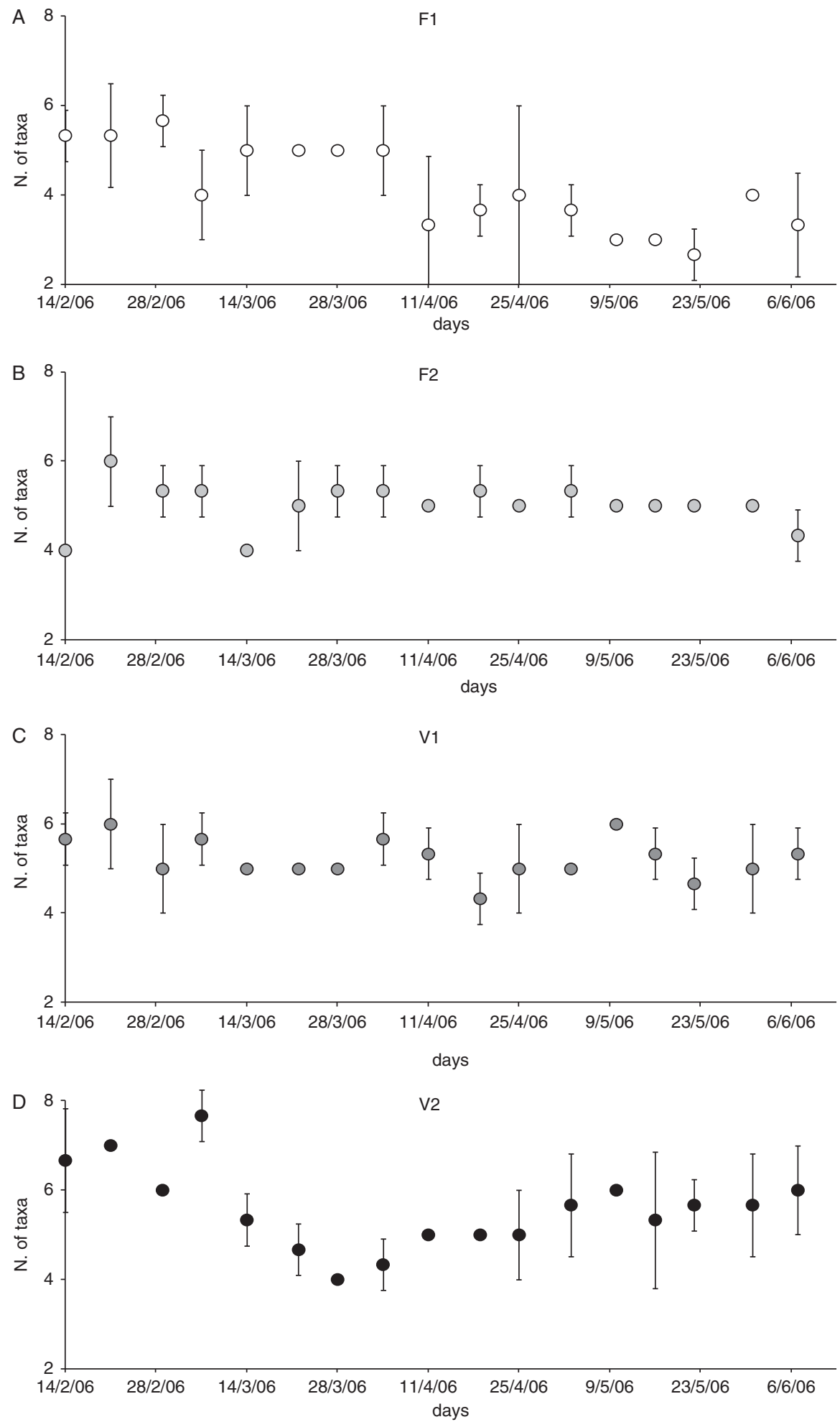

Figure 5. Richness of meiobenthic taxa at all investigated ponds in all sampling times: (A) F1 (Sea Farm), (B) F2 (Sea Farm), (C) V1 (Saint Vincent) and (D) V2 (Saint Vincent). Values are displayed as means \pm SD. 


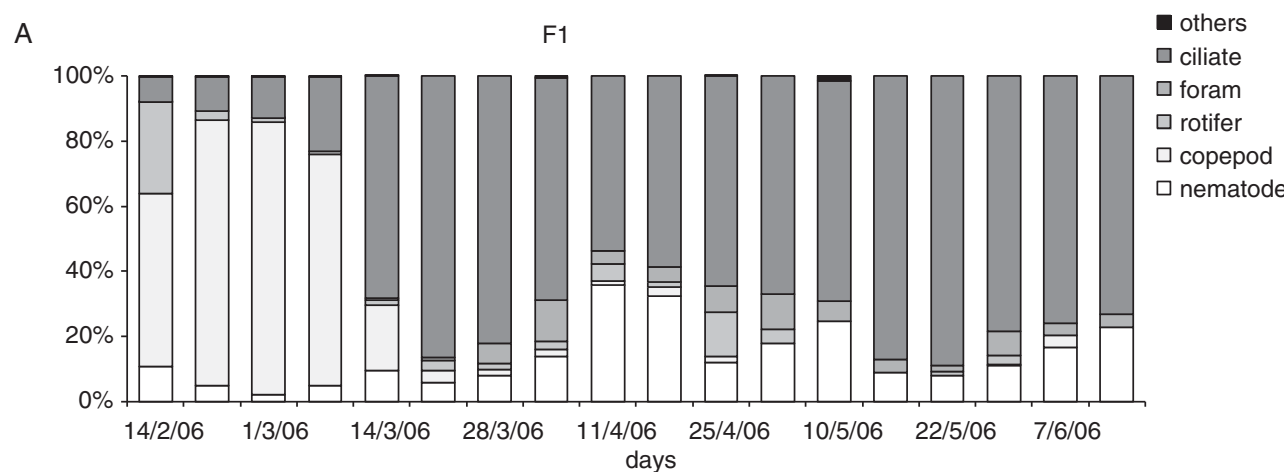

B F2

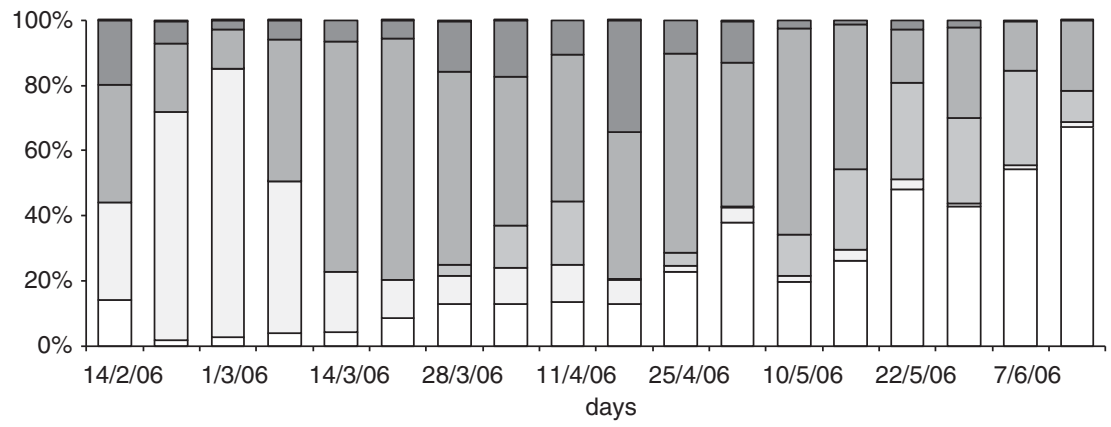

C

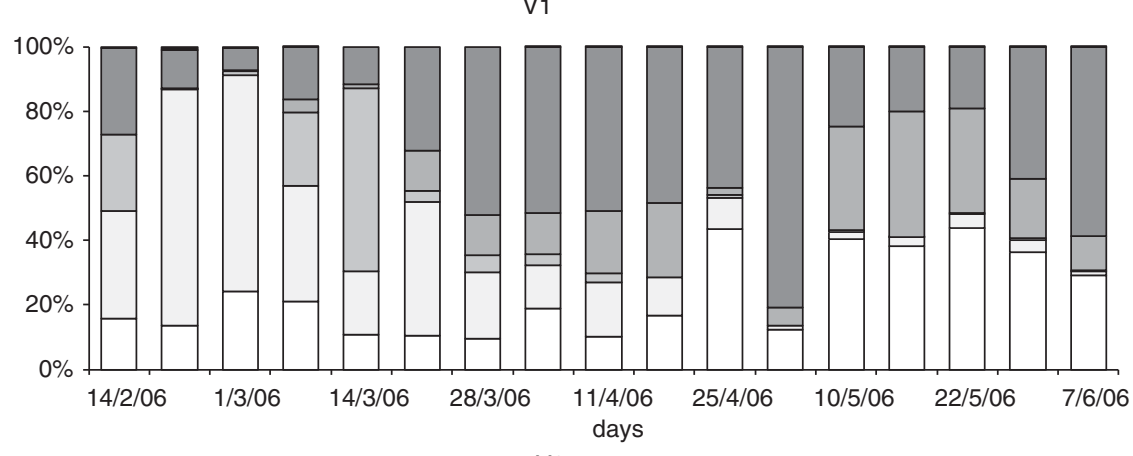

D V2

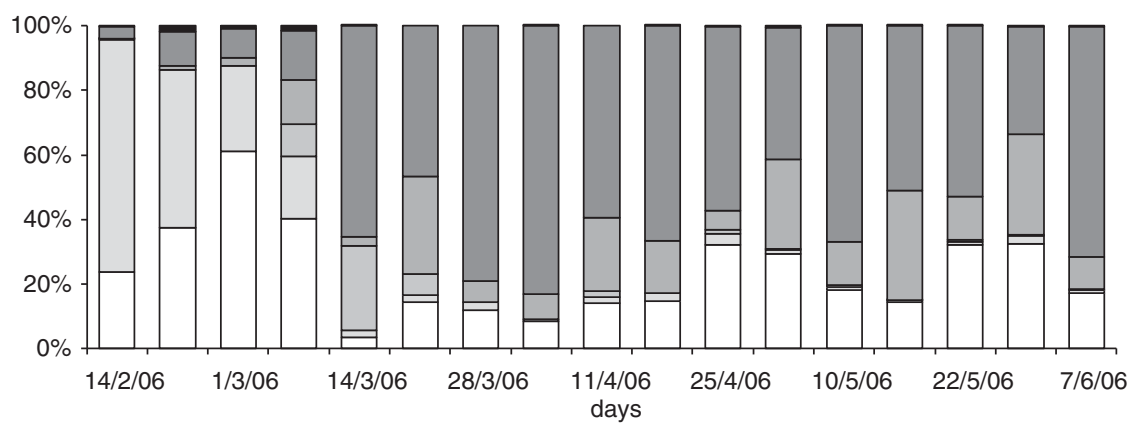

Figure 6. Meiobenthic community structure at all the investigated ponds of each shrimp farm: (A) F1 (Sea Farm), (B) F2 (Sea Farm), (C) V1 (Saint Vincent) and (D) V2 (Saint Vincent). 


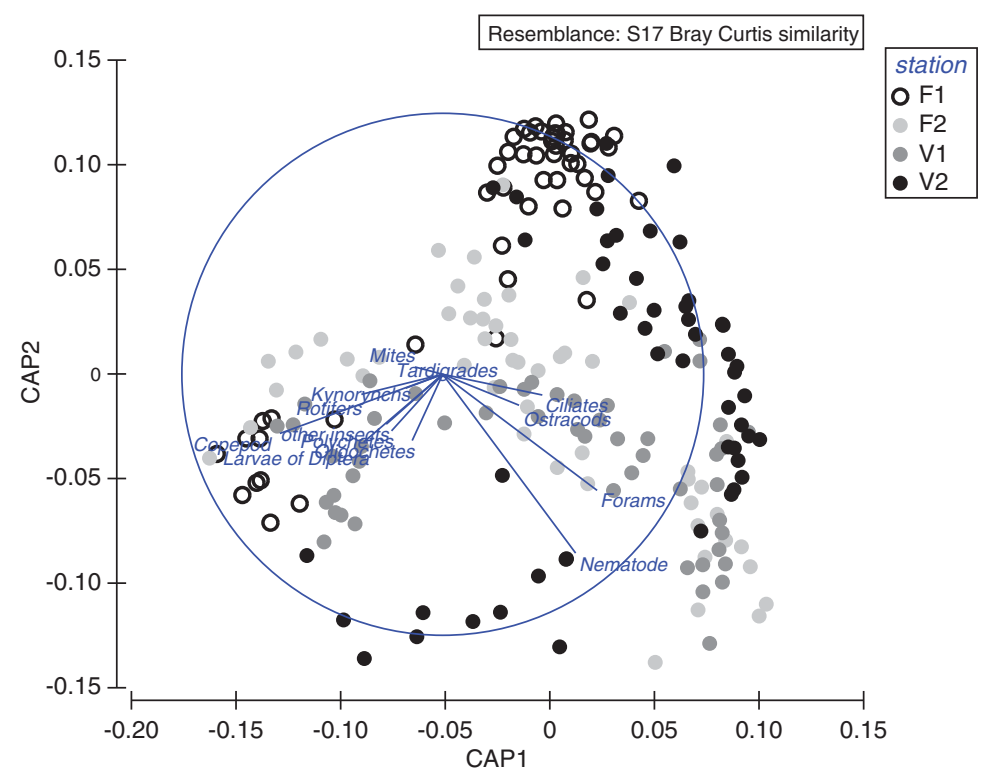

Figure 7. Biplot after the CAP analysis illustrating differences in meiobenthic community composition among ponds. Vectors are proportional to the fraction of variance explained along the axes.

sampling period the dissimilarity among the investigated ponds ranged from 20 to $40 \%$, while the dissimilarity among sampling periods in each pond ranged from 23 to $41 \%$ (Table 3). The observed differences are best visualised using bi-plots derived after a CAP in Figure 7.

The PERMANOVA analysis conducted on the composition of rare taxa assemblages revealed a significant effect of Pond $\times$ Time interaction (Table 4). The SIMPER analyses revealed that the dissimilarity among sampling periods in each pond ranged from 57 to $98 \%$, whereas in each sampling period the dissimilarity among ponds ranged from 36 to $86 \%$ (Table 5). In each pond and sampling time, different assemblages of rare taxa were responsible for the observed spatial-temporal dissimilarities (Table 5).

\subsection{Relationships between meiobenthic community composition and environmental conditions}

The results of the multivariate multiple regression analyses (DISTLM) conducted separately for meiobenthic abundance and richness of taxa are reported in Table 6 . Sediment $\mathrm{pH}$, biopolymeric $\mathrm{C}$ sedimentary content, food provided to the shrimps and protein sedimentary content were the most important factors explaining variations in the meiobenthic abundance (cumulatively, $47 \%$ of the explained variance), whereas sediment $\mathrm{pH}$, phaeopigment, protein, total organic matter and lipid sedimentary contents were the most important factors explaining variations in the richness of meiobenthic taxa (cumulatively, 67\% of the explained variance) (Table 6).

The results of the multivariate multiple regression analyses (DISTLM) conducted separately for the whole and the rare meiobenthic taxa composition and the meiofaunal vs. protistan assemblages are reported in Table 7. The food provided to shrimps, sediment $\mathrm{pH}$, protein, lipid, carbohydrate and oxygen concentration were the most important factors explaining variations in the meiofaunal taxonomic composition (cumulatively, 55\% of the explained variance), whereas all the considered environmental variables, but biopolymeric $\mathrm{C}$ concentration and sediment $\mathrm{pH}$, explained significant proportions of the observed differences in the rare meiobenthic taxa community composition (cumulatively, $57 \%$ of the explained variance) (Table 7). 
Table 3. Dissimilarity in meiobenthic community composition among the investigated ponds within each sampling time and among the sampling times within each investigated pond.

\begin{tabular}{lclc}
\hline & $\begin{array}{c}\text { Dissimilarity } \\
(\%)\end{array}$ & \multicolumn{1}{c}{ Responsible taxa } & $\begin{array}{c}\text { Cumulative contribution to } \\
\text { dissimilarity (\%) }\end{array}$ \\
\hline Among ponds & & & \\
Time 1 & 40.3 & Copepods, ciliates, nematodes, rotifers & 99.9 \\
Time 2 & 27.4 & Copepods, nematodes, ciliates & 97.1 \\
Time 3 & 23.2 & Copepods, nematodes, ciliates & 97.9 \\
Time 4 & 38.9 & Copepods, nematodes, ciliates, rotifers & 94.7 \\
Time 5 & 34.0 & Ciliates, rotifers, copepods & 91.4 \\
Time 6 & 37.4 & Ciliates, copepods, forams, nematodes & 94.7 \\
Time 7 & 36.3 & Ciliates, copepods, nematodes, rotifers & 93.9 \\
Time 8 & 27.7 & Ciliates, nematodes, forams, copepods & 94.3 \\
Time 9 & 23.8 & Ciliates, nematodes, forams, copepods & 96.1 \\
Time 10 & 20.8 & Ciliates, nematodes, forams, rotifers & 94.2 \\
Time 11 & 28.4 & Ciliates, nematodes, rotifers & 92.4 \\
Time 12 & 30.8 & Ciliates, nematodes, forams & 93.7 \\
Time 13 & 20.3 & Ciliates, nematodes, forams & 97.8 \\
Time 14 & 23.3 & Ciliates, forams, nematodes & 97.8 \\
Time 15 & 26.2 & Ciliates, nematodes, forams & 97.3 \\
Time 16 & 27.1 & Ciliates, nematodes, forams & 97.6 \\
Time 17 & 22.7 & Ciliates, nematodes, forams & 98.5 \\
Among samplings & \\
Pond F1 & 41.3 & Ciliates, copepods, nematodes & 95.1 \\
Pond F2 & 25.5 & Ciliates, nematodes, copepods, forams & 91.1 \\
Pond V1 & 25.0 & Ciliates, nematodes, copepods, forams & 93.1 \\
Pond V2 & 23.3 & Ciliates, nematodes, forams, copepods & 97.7 \\
\hline
\end{tabular}

Note: Values reported are the results of the SIMPER analyses, run with a $90 \%$ cut-off.

Table 4. Results of permutational ANOVA testing for spatial-temporal changes in the rare meiobenthic taxa community composition.

\begin{tabular}{lrrrr}
\hline Source & DF & \multicolumn{1}{c}{ MS } & \multicolumn{1}{c}{$F$} & $p$ \\
\hline Pond & 3 & 20,264 & 6754.6 & - \\
Time & 16 & 91,923 & 5745.2 & - \\
Pond $\times$ Time & 25 & 65,461 & 2618.4 & $* * *$ \\
Residual & 49 & 63,161 & 1289 & \\
Total & 93 & 293,610 & & \\
\hline
\end{tabular}

Note: DF, degrees of freedom; MS, mean squares; *** $p<0.001$.

The food provided to shrimps, sediment redox potential, lipid, protein and total organic matter sedimentary contents were the most important factors explaining variations in the relative importance of meiofauna vs. protistan abundance (cumulatively, 55\% of the explained variance, Table 7).

\section{Discussion}

\subsection{Shrimp farm effects on the abundance of meiobenthos}

Different sources of disturbance, including human impacts, may generate a plethora of changes in the abundance and structure of marine benthic assemblages [23,24,27]. In recent years, many studies have investigated the effects of fish-farm plants on structural and functional attributes of 
Table 5. Dissimilarity in the rare meiobenthic taxa community composition among the investigated ponds within each sampling time and among sampling times within each investigated pond.

\begin{tabular}{|c|c|c|c|}
\hline & $\begin{array}{c}\text { Dissimilarity } \\
(\%)\end{array}$ & Responsible taxa & $\begin{array}{c}\text { Cumulative } \\
\text { contribution to } \\
\text { dissimilarity }(\%)\end{array}$ \\
\hline \multicolumn{4}{|c|}{ Among ponds } \\
\hline Time 1 & 70.3 & larvae of Diptera, other insects & 100.0 \\
\hline Time 2 & 65.1 & larvae of Diptera, oligochaetes & 97.9 \\
\hline Time 3 & 77.7 & larvae of Diptera, oligochaetes & 100.0 \\
\hline Time 4 & 85.3 & Oligochetes, larvae of Diptera & 98.3 \\
\hline Time 5 & na & na & na \\
\hline Time 6 & 83.3 & Oligochaetes & 100.0 \\
\hline Time 7 & na & na & na \\
\hline Time 8 & na & na & na \\
\hline Time 9 & na & na & na \\
\hline Time 10 & 85.7 & Ostracods & 100.0 \\
\hline Time 11 & na & na & na \\
\hline Time 12 & 62.9 & Ostracods & 98.6 \\
\hline Time 13 & 53.5 & Ostracods & 100.0 \\
\hline Time 14 & 55.6 & Ostracods & 100.0 \\
\hline Time 15 & 40.0 & Ostracods & 100.0 \\
\hline Time 16 & 50.4 & Ostracods & 100.0 \\
\hline Time 17 & 35.9 & Ostracods & 98.3 \\
\hline \multicolumn{4}{|c|}{ Among samplings } \\
\hline Pond F1 & 98.4 & larvae of Diptera, insect larvae & 100.0 \\
\hline Pond F2 & 92.2 & larvae of Diptera, oligochaetes & 100.0 \\
\hline Pond V1 & 62.8 & Ostracods, larvae of Diptera & 97.1 \\
\hline Pond V2 & 57.2 & Ostracods, oligochaetes, larvae of Diptera & 94.5 \\
\hline
\end{tabular}

Note: Values reported are the results of the SIMPER analyses, run with a $90 \%$ cut-off. na, data not available, due to the absence of rare taxa.

marine benthic ecosystems [43]. However, changes associated with the presence of aquaculture wastes are often controversial or not consistent over space and time. It has been reported that benthic assemblages abundance may either increase or decrease beneath fish cages, depending on the study area, habitat or farm characteristics $[24,32,44,45]$.

The results of this study show that, cumulatively, total meiobenthic abundance in earthen ponds used for shrimp farming is noticeably high and displays significant temporal changes in all ponds. In particular, in three of the four ponds, total abundance showed similar temporal variability patterns, regardless of the initial conditions or the rearing practices. The only exception was represented by the F1 pond, in which meiobenthic abundance constantly and considerably decreased from March to the end of the study. Such changes in total abundance were consistently coupled with changes in the physical-chemical characteristics and trophic conditions of the sediment during the rearing period. It is worth noticing that the increase in total meiobenthic abundance in the F2 and V2 ponds was associated with decreased organic contents in the sediment and an overall tendency towards a less pronounced eutrophication of those basins [2]. However, the progressive increase in the sedimentary organic matter contents observed in the F2 pond sediments, which experienced a more pronounced eutrophication, affected negatively the whole meiobenthic community. This result is aligned with previous evidence of a rapid and negative response of meiofauna to the accumulation of biopolymeric $\mathrm{C}$ in the sediment and the associated oxygen depletion in dystrophic coastal lagoons [25] and sediments beneath fish cages [23,24].

The link between the changes in the total meiobenthic abundance and the shift in the sediment conditions was confirmed by the results of the multivariate multiple regression analysis, which indicated that both physical-chemical and trophic conditions (i.e. sediment $\mathrm{pH}$ and the 
Table 6. Results of multivariate multiple regression analysis carried out on total meiobenthic abundance and richness of taxa.

\begin{tabular}{|c|c|c|c|c|}
\hline \multirow[b]{2}{*}{ Variable } & \multirow[b]{2}{*}{$F$} & \multirow[b]{2}{*}{$p$} & \multicolumn{2}{|c|}{ Explained variance $(\%)$} \\
\hline & & & Single & Cumulative \\
\hline \multicolumn{5}{|l|}{ Abundance } \\
\hline $\mathrm{pH}$ & 17.1 & $* * *$ & 22.8 & 22.8 \\
\hline Biopolymeric C & 13.7 & $* * *$ & 13.3 & 36.1 \\
\hline Food & 4.3 & $*$ & 5.4 & 41.5 \\
\hline Protein & 4.2 & $*$ & 5.0 & 46.5 \\
\hline Organic matter & 2.5 & $\mathrm{~ns}$ & 2.4 & 48.9 \\
\hline Carbohydrate & 1.6 & $\mathrm{~ns}$ & 1.5 & 50.4 \\
\hline Phytopigment & 1.6 & $\mathrm{~ns}$ & 1.5 & 51.8 \\
\hline Chlorophyll $a$ & 1.3 & $\mathrm{~ns}$ & 1.2 & 53.1 \\
\hline Redox & 1.2 & $\mathrm{~ns}$ & 1.2 & 54.2 \\
\hline Phaeopigment & 1.3 & ns & 1.2 & 55.4 \\
\hline Organic C & 0.8 & $\mathrm{~ns}$ & 0.8 & 56.2 \\
\hline Oxygen & 0.7 & $\mathrm{~ns}$ & 0.6 & 56.8 \\
\hline Lipid & 0.5 & $\mathrm{~ns}$ & 0.5 & 57.3 \\
\hline \multicolumn{5}{|l|}{ Taxa richness } \\
\hline $\mathrm{pH}$ & 48.6 & $* * *$ & 45.6 & 45.6 \\
\hline Phaeopigment & 9.6 & $* *$ & 6.2 & 51.8 \\
\hline Protein & 7.2 & $* *$ & 5.8 & 57.5 \\
\hline Organic matter & 9.3 & $* *$ & 5.2 & 62.7 \\
\hline Lipid & 5.5 & $*$ & 4.1 & 66.9 \\
\hline Chlorophyll $a$ & 3.7 & $\mathrm{~ns}$ & 3.4 & 70.2 \\
\hline Organic C & 2.4 & $\mathrm{~ns}$ & 1.3 & 71.5 \\
\hline Biopolymeric C & 1.7 & $\mathrm{~ns}$ & 0.9 & 72.5 \\
\hline Phytopigment & 1.4 & $\mathrm{~ns}$ & 0.8 & 73.2 \\
\hline Food provided & 1.2 & ns & 0.6 & 73.9 \\
\hline Oxygen & 1.1 & ns & 0.6 & 74.5 \\
\hline Redox & 0.8 & ns & 0.4 & 74.9 \\
\hline Carbohydrate & 0.0 & ns & 0.0 & 74.9 \\
\hline
\end{tabular}

concentration of biopolymeric $\mathrm{C}$, aliment and protein) were responsible for $\sim 46 \%$ of the variance of the total abundance. Previous analysis of the investigated ponds indicated that shrimp farming led to only limited variations in the benthic trophic status of the four ponds, whatever the farming practice adopted (i.e. in terms of feeding strategy and density of reared specimens) and the initial environmental and trophic conditions of the sediment [2]. The results of this study indicate that the even limited shifts in the benthic trophic status as those observed in the ponds under scrutiny may have a detectable effect on the meiobenthic communities.

\subsection{Shrimp farming effects on meiobenthic community structure}

The general outcome of a detailed analysis of the available literature is that aquaculture effluents alter not only benthic abundance and biomass, but also diversity and community composition $[27,32,44]$. However, changes in the meiobenthic biodiversity associated with the presence of aquaculture effluents are often not consistent. A recent study, conducted in different habitats of the Mediterranean Sea, reported that biodeposition due to fish farm effluents can cause a reduction in the richness of higher meiofaunal taxa, but also that the changes in the community structure are region- and even habitat specific [24,45-47]. The richness of higher taxa showed the same patterns observed for total meiobenthic abundance, regardless of the initial conditions or the rearing practices adopted. These results suggest that the investigated benthic communities can 
Table 7. Results of the multivariate multiple regression analysis carried out on total and rare meiobenthic taxa community composition and on the relative importance of metazoan vs. protist abundance.

\begin{tabular}{|c|c|c|c|c|}
\hline Variable & $F$ & $p$ & $\%$ Var & $\%$ cumulative \\
\hline \multicolumn{5}{|l|}{ All taxa } \\
\hline Food & 20.9 & $* * *$ & 22.8 & 22.8 \\
\hline $\mathrm{pH}$ & 11.3 & $* * *$ & 12.2 & 35.0 \\
\hline Protein & 9.4 & $* * *$ & 8.4 & 43.4 \\
\hline Lipid & 5.7 & $* * *$ & 4.7 & 48.1 \\
\hline Carbohydrate & 4.0 & $* *$ & 4.1 & 52.2 \\
\hline Oxygen & 3.6 & $*$ & 2.8 & 55.0 \\
\hline Redox & 2.3 & ns & 1.7 & 56.7 \\
\hline Organic matter & 2.3 & $\mathrm{~ns}$ & 1.7 & 58.4 \\
\hline Phytopigment & 1.6 & ns & 1.2 & 59.6 \\
\hline Organic C & 1.1 & ns & 0.8 & 60.4 \\
\hline Biopolymeric C & 0.1 & ns & 0.1 & 60.5 \\
\hline \multicolumn{5}{|l|}{ Rare taxa } \\
\hline Food & 12.9 & $* * *$ & 18.2 & 18.2 \\
\hline Phaeopigment & 5.8 & $* * *$ & 7.6 & 25.8 \\
\hline Lipid & 6.0 & $* * *$ & 6.0 & 31.8 \\
\hline Organic matter & 4.3 & $* * *$ & 5.3 & 37.1 \\
\hline Phytopigment & 3.9 & $* * *$ & 4.4 & 41.5 \\
\hline Carbohydrate & 3.6 & $* * *$ & 4.2 & 45.7 \\
\hline Protein & 2.5 & $*$ & 2.7 & 48.3 \\
\hline Redox & 2.4 & $*$ & 2.2 & 50.6 \\
\hline Oxygen & 2.2 & $*$ & 2.1 & 52.7 \\
\hline Chlorophyll $a$ & 2.1 & $*$ & 2.0 & 54.7 \\
\hline Organic C & 2.2 & $*$ & 2.0 & 56.7 \\
\hline Biopolymeric C & 0.7 & ns & 0.6 & 57.3 \\
\hline $\mathrm{pH}$ & 0.5 & ns & 0.4 & 57.7 \\
\hline \multicolumn{5}{|c|}{ Metazoan vs. protists } \\
\hline Food & 23.9 & $* * *$ & 29.2 & 29.2 \\
\hline Redox & 10.1 & $* * *$ & 10.7 & 39.9 \\
\hline Lipid & 8.6 & $* * *$ & 8.0 & 47.9 \\
\hline Protein & 5.0 & $*$ & 4.3 & 52.2 \\
\hline Organic matter & 3.9 & $*$ & 3.2 & 55.4 \\
\hline Phytopigment & 2.3 & ns & 1.8 & 57.2 \\
\hline Biopolymeric C & 1.6 & ns & 1.3 & 58.5 \\
\hline Phaeopigment & 1.3 & ns & 1.0 & 59.6 \\
\hline Chlorophyll $a$ & 0.6 & ns & 0.5 & 60.0 \\
\hline Organic C & 0.6 & ns & 0.5 & 60.5 \\
\hline Oxygen & 0.5 & ns & 0.4 & 60.9 \\
\hline $\mathrm{pH}$ & 0.3 & ns & 0.2 & 61.1 \\
\hline Carbohydrate & 0.1 & ns & 0.1 & 61.2 \\
\hline
\end{tabular}

Notes: \% Var, percentage of explained variance; $F, F$ statistic; $p$, probability level. $* * * p<0.001 ; * * p<0.01 ; * p<0.05$; ns, not significant.

respond quickly to changes in the physical-chemical characteristics and the trophic condition of the sediment during the shrimp rearing cycle. Indeed, we observed that different taxa responded differently to the impact of the shrimp farm practice. In this regard, we report here that the dissimilarity in the composition of the meiobenthic communities among sampling times was very high in each pond (up to 60\%), with nematodes, copepods and protists as the taxa most responsible for the observed temporal variability. We also report that during the shrimp farm rearing cycle, a shift between communities dominated by metazoans and communities dominated by protists occurred at all ponds. Moreover, we also report strong temporal changes in the rare meiobenthic taxa community composition in all ponds. 
These findings were confirmed by the multivariate multiple regression analysis which revealed that different sets of environmental variables explained the variations in the different components of meiofaunal assemblages. Biopolymeric $\mathrm{C}$ and lipid concentrations, and redox potential in the sediment explained the variance in the major taxa community structure (i.e. nematode and copepods), whereas $\mathrm{pH}$, carbohydrate and phytopigment concentrations explained the variations in the protistan community. Both meiobenthic metazoa and protists are known to be very sensitive to changes in the benthic trophic status. Previous studies indicated that metazoan meiobenthic organisms respond rapidly to environmental changes and food availability (e.g. hypoxia, organic enrichment) $[23,24,35]$. Moreover, benthic protists can also respond rapidly to organic enrichment and changes in the sediment trophic status $[46,48,49]$. Together, these results suggest that different meiobenthic taxa are characterised by different levels of tolerance to environmental change, including changes in benthic trophic status, as determined by shrimp farming activities.

Earthen shrimp ponds are artificial structures and are characterised by trophic conditions that are different from those observed other benthic marine coastal ecosystems (like mangrove, tropical seagrass and fish farm sediments), so that, their characteristics would prevent in principle any reliable comparison with natural environments. This study provides evidence that in earthen ponds used for shrimp farming, classified as the most eutrophic environments ever reported to date [2,39], even minor changes in the benthic trophic status may provoke clear changes of benthic communities. Such changes may be detectable in terms of abundance, richness of taxa, as well as in the composition of meiobenthic communities.

As the meiobenthic communities have a key ecological role in all aquatic ecosystems (i.e. representing the link between the microbial loop and the higher trophic levels), any change in those benthic components may underpin undesirable changes at the whole ecosystem level. The results of this study suggest that the meiobenthic communities represent a reliable descriptor of the environmental quality of shrimp farming ponds.

\section{References}

[1] M. Holmer, Environmental issues of fish farming in offshore waters: Perspectives, concerns and research needs, Aquacult. Environ. Int. 1 (2010), pp. 57-70.

[2] A. Pusceddu, L. Della Patrona, and B. Beliaeff, Trophic status of earthen ponds used for semi-intensive shrimp (Litopenaeus stylirostris, Stimpson, 1874) farming in New Caledonia (Pacific Ocean), Mar. Environ. Res. 72 (2011), pp. 160-171.

[3] R.L. Naylor, R.J. Goldburg, H. Mooneyt, M.C.M. Beveridge, J.W. Clay, C. Folke, N. Kautsky, J. Primavera, and M. Williams, Nature's subsidies to shrimp and salmon farming, Science 282 (1998), pp. 883-884.

[4] N.P. Preston, P.C. Rothlisberg, M.A. Burford, and C.J. Jackson, The Environmental Management of Shrimp Farming in Australia, Report prepared under the World Bank, NACA, WWF and FAO Consortium Program on Shrimp Farming and the Environment. Work in Progress for Public Discussion, 2002, 9 pp.

[5] Y. Thomas, C. Courties, Y. El Helwe, A. Herbland, and H. Lemonnier, Spatial and temporal extension of eutrophication associated with shrimp farm waste water discharges in the New Caledonia lagoon, Mar. Pollut. Bull. 61 (2010), pp. 387-398.

[6] F. Páez-Osuna, The environmental impact of shrimp aquaculture: Causes, effects, and mitigating alternatives, Environ. Manage. 28 (2001), pp. 131-140.

[7] J.S. Hopkins, P.A. Sandifer, M.R. De Voe, A.F. Holland, C.L. Browdy, and A.D. Stokes, Environmental impacts of shrimp farming with special reference to the situation in the continental United States, Estuaries 18 (1995), pp. 25-42.

[8] M. Flaherty and C. Karnjanakesorn, Marine shrimp aquaculture and natural resource degradation in Thailand, Environ. Manage. 19 (1995), pp. 27-37.

[9] J.H. Primavera, Socio-economic impacts of shrimp culture, Aquacult. Res. 28 (1997), pp. 815-827.

[10] J.H. Primavera, Tropical shrimp farming and its sustainability, in Tropical Mariculture, S. De Silva, ed., Academic Press, London, 1998, pp. 257-289.

[11] F. Páez-Osuna, S.R. Guerrero-Galvan, and A.C. Ruiz-Fernandez, The environmental impact of shrimp aquaculture and coastal pollution in Mexico, Mar. Pollut. Bull. 36 (1998), pp. 65-75.

[12] M.J. Phillips, Tropical mariculture and coastal environmental integrity, in Tropical Mariculture, S. De Silva, ed., Academic Press, London, 1998, pp. 17-69. 
[13] A.B. Jones, M.J. O’Donohue, J. Udy, and W.C. Dennison, Assessing ecological impacts of shrimp and sewage effluent: Biological indicators with standard water quality analyses, Estuar. Coast. Shelf Sci. 52 (2001), pp. 91-109.

[14] L.A. Trott and D.M. Alongi, The impact of shrimp pond effluent on water quality and phytoplankton biomass in a tropical mangrove estuary, Mar. Pollut. Bull. 40 (2000), pp. 947-951.

[15] A. Boyra, F.J.A. Nascimento, F. Tuya, P. Sanchez-Jerez, and R.J. Haroun, Impact of sea-cage fish farms on intertidal macrobenthic assemblages, J. Mar. Biol. Assoc. UK 84 (2004), pp. 665-668.

[16] A. Machias, I. Karakassis, M. Labropoulou, S. Somarakis, K.N. Papadopoulou, and C. Papaconstantinou, Changes in wild fish assemblages after the establishment of a fish farming zone in an oligotrophic marine ecosystem, Estuar. Coast. Shelf Sci. 60 (2004), pp. 771-779.

[17] R.J. Gowen and N.B. Bradbury, The ecological impact of salmonid farming in coastal waters: A review, Oceanogr. Mar. Biol. Annu. Rev. 25 (1987), pp. 563-575.

[18] S.R. Guerrero-Galván, F. Páez-Osuna, A.C. Ruiz-Fernánadez, and R. Espinoza-Angulo, Seasonal variation in the water quality and chloropyll a of semi-intensive shrimp ponds in a subtropical environment, Hyrobiologia 391 (1999), pp. 33-45.

[19] C. Jackson, N. Preston, P.J. Thompson, and M. Burford, Nitrogen budget and effluent nitrogen components at an intensive shrimp farm, Aquaculture 218 (2003), pp. 397-411.

[20] F. Páez-Osuna, S.R. Guerrero-Galván, A.C. Ruiz-Fernández, and R. Espinoza-Angulo, Fluxes and mass balances of nutrients in a semi-intensive shrimp farm in North-Western Mexico, Mar. Pollut. Bull. 34 (1997), pp. $290-297$.

[21] J.P. Debenay, L. Della Patrona, A. Herbland, and H. Goguenheim, The impact of easily oxidized material (EOM) on the meiobenthos: Foraminifera abnormalities in shrimp ponds of New Caledonia; implications for environment and paleoenvironment survey, Mar. Pollut. Bull. 59 (2009), pp. 323-335.

[22] S.P. Powers, C.H. Peterson, R.R. Christian, E. Sullivan, M.J. Powers, M.J. Bishop, and C.P. Buzzelli, Effects of eutrophication on bottom habitat and prey resources of demersal fishes, Mar. Ecol. Progr. Ser. 302 (2005) 233-243.

[23] C. Gambi, S. Bianchelli, M. Pérez, O. Invers, J.M. Ruiz, and R. Danovaro, Biodiversity response to experimental induced hypoxic-anoxic conditions in seagrass sediments, Biodiv. Conserv. 18 (2009), pp. 33-54.

[24] S. Mirto, S. Bianchelli, C. Gambi, M. Krzelj, A. Pusceddu, M. Scopa, M. Holmer, and R. Danovaro, Fish-farm impact on metazoan meiofauna in the Mediterranean Sea: Analysis of regional vs. habitat effects, Mar. Environ. Res. 69 (2010), pp. 38-47.

[25] A. Pusceddu, C. Gambi, E. Manini, and R. Danovaro, Trophic state, ecosystem efficiency and biodiversity of transitional aquatic ecosystems: Analysis of environmental quality based on different benthic indicators, Chem. Ecol. 23 (2007), pp. 1-11.

[26] M. Steyaert, L. Moodley, T. Nadong, T. Moens, K. Soetaert, and M. Vincx, Responses of intertidal nematodes to short-term anoxic events, J. Exp. Mar. Biol. Ecol. 345 (2007), pp. 175-184.

[27] T.F. Sutherland, C.D. Levings, S.A. Petersen, P. Poon, and B. Piercey, The use of meiofauna as an indicator of benthic organic enrichment associated with salmonid aquaculture, Mar. Pollut. Bull. 54 (2007), pp. 1249-1261.

[28] M. Grego, M. De Troch, J. Forte, and A. Malej, Main meiofauna taxa as an indicator for assessing the spatial and seasonal impact of fish farming, Mar. Pollut. Bull. 58 (2009), pp. 1178-1186.

[29] H. Modig and E. Olafsson, Responses of Baltic benthic invertebrates to hypoxic events, J. Exp. Mar. Biol. Ecol. 229 (1998), pp. 133-148.

[30] R. Danovaro, C. Gambi, E. Manini, and M. Fabiano, Meiofauna response to a dynamic river plume front, Mar. Biol. 137 (2000), pp. 359-370.

[31] R. Danovaro and C. Gambi, Biodiversity and trophic structure of nematode assemblages in seagrass systems: Evidence for a coupling with changes in food availability, Mar. Biol. 141 (2002), pp. 667-677.

[32] T. La Rosa, S. Mirto, A. Mazzola, and R. Danovaro, Differential responses of benthic microbes and meiofauna to fish-farm disturbance in coastal sediments, Environ. Pollut. 112 (2001), pp. 427-434.

[33] M.C. Austen and S. Widdicombe, Comparison of the response of meio- and macrobenthos to disturbance and organic enrichment, J. Exp. Mar. Biol. Ecol. 330 (2006), pp. 96-104.

[34] M. De Troch, D. Van Gansbeke, and M. Vincx, Resource availability and meiofauna in sediment of tropical seagrass beds: Local versus global trends, Mar. Environ. Res. 61 (2006), pp. 59-73.

[35] A. Pusceddu, S. Bianchelli, C. Gambi, and R. Danovaro, Assessment of benthic trophic status of marine coastal ecosystems: Significance of meiofaunal rare taxa, Estuar. Coast. Shelf Sci. 93 (2011), pp. 420-430.

[36] C. Heip, M. Vincx, and G. Vranken, The ecology of marine nematodes, Oceanogr. Mar. Biol. Annu. Rev. 23 (1985), pp. 399-489.

[37] R. Danovaro, Methods for the Study of Deep-Sea Sediments, Their Functioning and Biodiversity, CRC Press, Boca Raton, FL, 2010, 428 pp.

[38] S. Bianchelli, C. Gambi, D. Zeppilli, and R. Danovaro, Metazoan meiofauna in deep-sea canyons and adjacent open slopes: A large-scale comparison with focus on the rare taxa, Deep Sea Res. I 57 (2010), pp. 420-433.

[39] A. Pusceddu, A. Dell'Anno, M. Fabiano, and R. Danovaro, Quantity and bioavailability of sediment organic matter as signatures of benthic trophic status, Mar. Ecol. Progr. Ser. 375 (2009), pp. 41-52.

[40] M.J. Anderson and C.J.F. Ter Braak, Permutation tests for multi-factorial analysis of variance, J. Stat. Comp. Sim. 73 (2003), pp. 85-113.

[41] K.R. Clarke and R.N. Gorley, PRIMER v6: User Manual/Tutorial, PRIMER-E, Plymouth, 2006.

[42] B.H. McArdle and M.J. Anderson, Fitting multivariate models to community data: A comment on distance-based redundancy analysis, Ecology 82 (2001), pp. 290-297. 
[43] M. Holmer, M. Frederiksen, A. Pusceddu, R. Danovaro, S. Mirto, M. Perez, N. Marbà, C.M. Duarte, E. Diaz-Almela, M. Tsapakis, and Y. Karakassis, Effects of fish-farm waste on Posidonia oceanica meadows: Synthesis and provision of management tools, Mar. Pollut. Bull. 23 (2008), pp. 1618-1629.

[44] S. Mirto, T. La Rosa, C. Gambi, R. Danovaro, and A. Mazzola, Nematode community response to fish-farm impact in the Western Mediterranean, Environ. Pollut. 116 (2002), pp. 203-214.

[45] A. Pusceddu, S. Fraschetti, S. Mirto, M. Holmer, and R. Danovaro, Effects of intensive mariculture on sediment biochemistry, Ecol. Appl. 17 (2007), pp. 1366-1378.

[46] L. Bongiorni, S. Mirto, A. Pusceddu, and R. Danovaro, Response of benthic protozoa and Thraustochytrid protists to fish farm impact in seagrass (Posidonia oceanica) and soft-bottom sediments, Microb. Ecol. 50 (2008), pp. $268-276$.

[47] D. Balata, I. Bertocci, L. Piazzi, and U. Nesti, Comparison between epiphyte assemblages of leaves and rhizomes of the seagrass Posidonia oceanica subjected to different levels of anthropogenic eutrophication, Estuar. Coast. Shelf Sci. 79 (2008), pp. 533-540.

[48] E. Manini, C. Fiordelmondo, C. Gambi, A. Pusceddu, and R. Danovaro, Benthic microbial loop functioning in coastal lagoons: A comparative approach, Oceanol. Acta 26 (2003), pp. 27-38.

[49] P.N. Polymenakou, A. Pusceddu, A. Tselepides, T. Polychronaki, A. Giannakourou, C. Fiordelmondo, E. Hatziyanni, and R. Danovaro, Benthic microbial abundance and activities in an intensively trawled ecosystem (Thermaikos Gulf, Aegean Sea), Continent. Shelf Res. 25 (2005), pp. 2570-2584. 